\title{
DIVINIzação heróica E CATASTERISMOS NA poesia de VIRGílo: polissemia e apropriações poéticas do Cometa/Estrela de César
}

Thiago Eustáquio Araújo MOTA

\author{
(D) theamotta@gmail.com
}

\author{
Universidade de \\ Pernambuco, \\ Petrolina, PE, Brasil
}

\begin{abstract}
Heroic Divinization and Catasterisms in Virgil's Poetry: Polysemy and Poetic Appropriations of the Caesar's Comet/Star
\end{abstract}

\section{RESUMO}

O tema da divinização heroica, tanto de Hércules quanto de Enéias e Rômulo, ganhou amplo espaço na literatura augustana, em parte, graças à memória da consecratio de César, associado a um corpo celestial e cultuado, depois da morte, como diuus em um templo no Fórum Romano. Não apenas o tema da apoteose heroica, mas também o tópico da transmutação/elevação sideral, ou catasterismo, pertencente ao repertório dos mitos, foi usado como recurso poético para ilustrar a vinculação de César com o astro de 44 a.C. Buscamos demonstrar como este portento astral ganhou conotações variadas ao longo das três principais composições de Virgílio (Bucólicas, Geórgicas e Eneida) que se estendem por arco temporal de trinta anos. Através da análise hermenêutica abordaremos as representações da morte e da apoteose astral de César na poesia virgiliana tendo em vista as especificidades de gênero e a historicidade de cada poema.

Palavras-chave: Divinização, Catasterismo, Polissemia, Virgílio, Astrum Caesaris

\begin{abstract}
The topic of heroic divinization, of Hercules, Aeneas and Romulus, gained wide acceptance in Augustan literature, thanks in part to the memory of Caesar's consecration, associated with a celestial body and worshiped after death, as diuus in a temple of the Roman Forum. Not only the theme of heroic apotheosis, but also the topic of sidereal elevation, or catasterism, belonging to the repertoire of myths, was used as a poetic resource to illustrate Caesar's connection with the star of $44 \mathrm{BC}$. This paper intends to demonstrate how this astral portent gained varied connotations throughout Vergil's main poems (Bucolics, Georgics, and Aeneid) that span a period of more than thirty years. Through hermeneutic analysis we seek to approach the representations of Caesar's death and astral apotheosis in Virgilian poetry, in view of different genres and the historicity of each poem.
\end{abstract}

Keywords: Divinization, Catasterism, Polysemy, Virgílio, Astrum Caesaris 
D esde a Antiguidade, cometas e asteroides são objetos de fascínio e apreensão. Com alguma regularidade o mundo é surpreendido pelos boletins das agências espaciais que noticiam a passagem destes objetos pela "vizinhança" da Terra. Completaram-se pouco mais de três anos da passagem do Oumuamua pelo Sistema Solar e sua origem e classificação continuam dividindo opiniões na comunidade científica. O nome havaiano de batismo, que se traduz por "mensageiro de muito longe que chega primeiro", associado ao formato invulgar do asteroide, gerou toda sorte de especulação nos tabloides de divulgação'. Alguns destes corpos celestes podem ser vistos a olho nu, como determinados cometas na fase de periélio, momento em que a famosa cauda, formada de gases, gelo e poeira torna-se evidente. A aproximação do cometa Halley, em um ciclo de 75-76 anos, é talvez um dos eventos astronômicos mais aguardados da Terra e sua última passagem inspirou desde contos de ficção científica, revistas de $\mathrm{HQ}$ até campanhas publicitárias. Se hoje conseguimos prever com alguma satisfação o período orbital de alguns cometas, a súbita aparição destes objetos nos céus impunha um desafio às categorias de explicação dos povos da Antiguidade. Entre os romanos, por exemplo, os cometas eram conhecidos como 'estrelas comadas' e sua passagem despertava reações diversas que iam da curiosidade investigativa ao temor fatídico. O corpo celeste que cortou os céus de Roma em 44 a.C., ano do assassinato de Caio Júlio César, foi reportado por autores de diferentes gerações e, por conseguinte, ganhou conotações variadas ao longo do tempo.

Símbolo da transição do Ditador para o domínio dos imortais, a estrela de César ou Sidus lulium², como ficou conhecida através de uma das Odes de Horácio (HORÁcIO, Odes, I, 12), foi incorporada à iconografia oficial e largamente propagandeada por Otávio que acolheu, para o seu proveito, o epíteto de Filius Diui "Filho de um Divino". Dessa maneira o portento foi descrito em um trecho dos Commentarii de Augusto, reproduzido por Plínio, no Livro II da História Natural

[iis ipsis ludorum meorum diebus sidus crinitum per septem dies in regione caeli sub septentrionibus est conspectum. id oriebatur circa undecimam horam diei clarumque et omnibus e terris conspicuum fuit. eo sidere significari vulgus credidit Caesaris animam inter deorum immortalium numina receptam, quo nomine id insigne simulacro capitis eius, quod mox in foro consecravimus, adiectum est] (PLíNIO, História Natural, II, 93).

[Quando naqueles próprios dias dos meus jogos, um astro comado [cometa] por sete dias, na região do céu, sob a Ursa Menor, foi avistado. Ele surgiu, por volta da décima primeira hora do dia, radiante e por toda a parte foi visível. A população confiou naquele astro ser revelado que a alma de César fora recebida entre os numes dos deuses imortais, porque aquele sinal, com o nome, foi adicionado à estátua de César, que pouco depois no Fórum consagramos] (Tradução nossa).

Uma vez que Otávio não se encontrava em Roma durante o funeral do Ditador, o astro que brilhou nos céus da urbs, durante a realização dos Jogos em honra de Vênus Genetrix - Ludi Veneris Genetricis - foi utilizado como signo palpável para 
que se consubstanciasse o processo de apoteose. Este excerto encontra-se em um dos capítulos da História Natural dedicado à investigação dos cometas e toda sorte de corpos celestes. Sobre o evento narrado, Plínio acrescenta que "Um cometa é venerado em um único local de todo o mundo, em um templo de Roma [Tradução nossa]" - Cometes in uno totius orbis loco colitur in templo Romae (PLíNIO, História Natural, II, 93). Por templo o naturalista refere-se ao Aedes Diui luli, construído no mesmo local do Fórum onde o corpo de César foi cremado pela multidão que compareceu ao funeral. Assume-se, pela referência, que nesta edificação existia uma estátua de culto (simulacrum) do Diuus Iulius com o ornamento de um cometa (sidus crinitum) afixado à fronte.

J. Ramsey e A. Licht, autores do livro The Comet of 44 B.C. and Caesar's Funeral Games, conjecturaram a partir de relatos da Dinastia Han na China e de cálculos astronômicos a órbita deste cometa ${ }^{3}$ - batizado C/-43 K1 - com o propósito de refutar a ideia de que se tratava de uma fabricação da propaganda augustana (RAMSEY; LICHT, 1997). Por conseguinte, estes pesquisadores argumentam que Otávio persuadiu a opinião pública ${ }^{4}$ a aceitar o cometa como um sinal auspicioso da apoteose de César. Fato que se coadunaria com a ideia de que o herdeiro, desse modo, desejava abrir caminho para sua futura deificação (RAMSEY; LICHT, 1997, p. 65) ${ }^{5}$.

Esta interpretação, no entanto, toma por base relatos que são bem posteriores ao acontecimento. A respeito do episódio dos Jogos de 44 a.C., Dion Cássio (século II d.C.) na História Romana menciona que "embora alguns afirmassem que se tratava de um cometa - kouńtnv - anunciante de usuais acontecimentos, a população se recusou a acreditar neles, tomando-o como um sinal de que César havia se tornado imortal - $\alpha \pi \eta \theta \alpha v \alpha \tau 1 \sigma \mu \varepsilon ́ v \omega$ - e incorporado ao conjunto dos astros" (DION CÁSSIO, História Romana, XLV, 7.1) O historiador do Período Severiano ainda acrescenta a informação de que "Otávio, cheio de confiança, fixou uma estátua de bronze de César no Templo de Vênus com uma estrela sobre a cabeça” (DION CÁSSIO, História Romana, XLV, 7.1). Uma passagem de Mauro Sérvio Honorato, gramático do Século IV d.C. e comentador da obra de Virgílio, sugere também esta ideia de que a "população acreditou ser [a estrela de César] através da persuasão de Augusto" - persuasione Augusti Caesaris esse populus credidit (SÉRVIO, Comentário à Eneida, VI, 790). Muito provavelmente as descrições de Sérvio e Dion Cássio partem da mesma fonte citada por Plínio na História Natural: as Memórias de Augusto ou mais precisamente os Commentarii de Vita Sua, compostos e publicados por volta dos anos 20 a.C. (SMITH; POWELL, 2009).

Cabe ressaltar que a divinização de César não foi um processo linear, desprovido de adversidades, tão pouco, Otávio deteve o poder absoluto sobre as representações ou opiniões acerca deste fenômeno celeste que aparece na documentação literária e iconográfica do período de forma tão variada ${ }^{6}$. Como reflexo da divergência de opiniões acerca deste portento astronômico e considerando, também, a própria linguagem polissêmica dos textos poéticos, está ausente da poesia de Virgílio uma representação coesa ou linear da divinização de César. A ausência de referências ao corpo celeste em toda a documentação de Cícero torna a poesia de Virgílio e Horácio os registros literários, datáveis, mais próximos deste acontecimento. Historicamente, 
o processo de consecratio de César se completou apenas em 42 a.C., quando sua divindade foi oficialmente decretada pelo Senado. Segundo Michael Koortbojian, autor do livro The Divinization of Caesar and Augustus: Precedents, Consequences, Implications, a rivalidade entre Otávio e Antônio e a instabilidade política de todos os lados criou impedimentos para este processo (KOORTBOJIAN, 2013, p. 05-13).

De acordo com o Oxford Latin Dictionary, consecratio traz a acepção básica de 'consagração', algo profano convertido em sagrado ou 'deificação', no caso de seres humanos (GLARE, 1968, p. 411). Deriva do verbo consecro que expressa três ações adjacentes: primeiramente, render ou dedicar um objeto ou construção a uma divindade; consagrar, no sentido de atribuir sacralidade; e, por fim, assinalar a divindade, reconhecer como divino (GLARE, 1968, p. 411-412). No livro Roman Gods: A Conceptual Approach, Michael Lipka declara que virtualmente qualquer recinto, espaço, objeto e até mesmo noções abstratas poderiam ser deificadas no sistema religioso romano, passando a receber algum tipo de culto ou adoração (LIPKA, 2009, p. 127).

No caso da deificação de pessoas, não existe registro deste procedimento nos tempos republicanos; ao que tudo indica, na trilha de Rômulo, César parece ter sido o primeiro caso de divinização oficial com a instituição de um culto, templo e rituais (LIPKA, 2009, p. 129). Apesar do reconhecimento de atributos divinos a alguns generais romanos, como Camilo, Cipião Africano e Caio Mário7 nada como o aumento do panteão romano consta na documentação. Não é nosso propósito discutir se as honrarias divinas foram atribuídas ao Ditador, ainda em vida ou post mortem, uma vez que o assunto já foi abordado magistralmente por pesquisadores como Stefan Weinstock (1971), Lily Ross Taylor (1975), Ittai Gradel (2002), Geoffrey Sumi (2008) e Cláudia Beltrão da Rosa (2013). Importa ressaltar apenas que o processo de instituição de um novo deus e a organização do culto não deixou de gerar controvérsia, bem como sua identificação com o corpo celeste de 44 a.C. Na falta de precedentes históricos recentes, a correspondência com os heróis semideuses, especialmente Hércules, Eneias e Rômulo, foi um paralelo oportuno encontrado pelos poetas e autores da geração de Otávio para explicar a transformação do Ditador assassinado em potestade.

Segundo Patrizio Domenicucci, no capítulo "Catasterismo, Astrologia e Astronomia nell'Impero", assim como boa parte das culturas da Antiguidade, a civilização romana instaurou uma ligação profunda e articulada com os astros que compreendia funções práticas como orientação, escansão do tempo, previsões meteorológicas e, no âmbito da filosofia e da religião, um sistema de crenças que buscava prever os influxos dos astros sobre os destinos coletivos ou individuais (DOMENICUCCI, 2014, p. 139). Por conseguinte, "a ideia de que a abóboda celeste era um local destinado às almas virtuosas, como uma espécie de recompensa radiante, ganhou acolhida entre os autores romanos, principalmente através dos textos filosóficos ${ }^{8}$ e das narrativas de metamorfose astral" ou catasterismos (DOMENICUCCI, 2014, p. 139).

No léxico grego do período helenístico, entende-se por catasterismós -

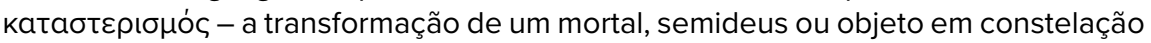

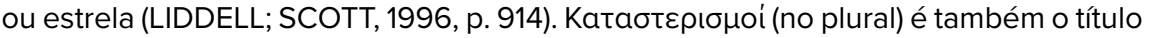
dado a um tratado pseudoepigráfico de Eratóstenes de Cirene que descreve a origem 
mítica das estrelas e constelações. Deste trabalho em prosa, nos chegou apenas um epítome, organizado no final do Século I, que compreende a súmula de mais de quarenta narrativas etiológicas de objetos e figuras da idade dos deuses e heróis que sofreram asterismo, ação que geralmente era impulsionada por uma divindade. A julgar pelas recorrentes citações a Hesíodo, Sófocles, Eurípedes e Arato esta obra consistia em uma compilação de mitografias estelares associadas à observação sistemática dos astros, característica dos estudos astronômicos da época. ${ }^{9}$ Segundo o classicista português Rui Carlos Fonseca "essa transferência do elemento finito para a morada infinita dos astros constitui uma forma de tornar imortal a natureza outrora mortal do ser agraciado na medida em que este (...) se faz inolvidável”. (FONSECA, 2016, p. 95).

Como narrativa etiológica, o catasterismo não está circunscrito aos seres do passado heroico. De igual relevância, cabe considerar o poema de Calímaco que celebra a constelação "Coma de Berenice" ou "Trança de Berenice" descoberta por Conon de Alexandria e batizada em homenagem à Berenice II, esposa de Ptolomeu III, Evergetes ${ }^{10}$. Várias destas etiologias astrais aparecem diluídas na poesia virgiliana e de outros poetas latinos como Catulo, Horácio e Ovídio"1. Se, por um lado, os romanos conheciam todo um repertório de mitos sobre as transmutações astrais como é apresentada a vinculação do Diuus lulius a algo imprevisível e transitório como um cometa?

Os textos poéticos não oferecem uma resposta simples para essa questão. Virgílio, em uma de suas primeiras composições, evitou nomeá-lo diretamente pela palavra cometes, optando pela denominação astrum Caesaris 'astro de César' nas Bucólicas, e 'Patrium Sidus' 'estrela paterna' na Eneida (VIRGÍLIO, Bucólica, IX, 47; Eneida, VIII, 681). Por sua vez, a aproximação de César com os cometas não deixa de ser estimulada pela manipulação da écfrase ${ }^{12}$ e da analogia, em passagens das Geórgicas e da Eneida. Os catasterismos são usados como um paralelo interessante, não apenas para as múltiplas apropriações do portento de 44 a.C., mas também para anunciar a apoteose de personagens como Hércules e Enéias nos termos de uma ascensão sideral. Destarte, o cometa/estrela de César, ou astrum Caesaris, ganhou conotações variadas no que diz respeito às três principais composições de Virgílio (Bucólicas, Geórgicas e Eneida), que se estendem por um arco temporal de quase trinta anos.

Por uma questão de factibilidade metodológica e recorte, o presente artigo se centrará nos poemas virgilianos. Através da análise hermenêutica, abordaremos as apropriações poéticas da morte e da apoteose astral de César nos textos de Virgílio tendo em vista as especificidades de gênero e a historicidade de cada poema. Compreendemos por apropriação poética ${ }^{13}$ a transmutação de fenômenos visíveis, palatáveis e sensoriais em textos que a rigor seguem inúmeras convenções métricas e formais. Uma vez que estas apropriações não estão explícitas nos textos virgilianos, delimitá-las parte de um esforço hermenêutico de desmontagem e intelecção dos poemas e do cotejamento com outras fontes literárias do período. Segundo Jörn Rüsen, no livro Reconstrução do Passado, cumpre ao historiador, através da crítica documental e do exercício hermenêutico, interpretar os sentidos das experiências 
do passado, deve o mesmo problematizar as manifestações que exteriorizam as intenções dos homens de outrora e a temporalidade que as condiciona (RÜSEN, 2010, p. 141-143). Porém, é preciso ter em vista que a linguagem poética nem sempre se expressa com a coerência que se requer da epigrafia oficial e das mensagens de cunho propagandístico, uma vez que está aberta a inúmeras possibilidades de leitura e, por vezes, saturada de ambiguidades. Assim, uma reflexão sobre o vocabulário pertinente à divinização heroica e às várias narrativas de apoteose astral nos poemas do Virgílio se faz necessária para abordarmos as distintas manifestações do cometa/ estrela de 44 a.C.

\section{O Astrum Caesaris nas Bucólicas:}

Compostas entre 42 e 38 a.C., aproximadamente, as Bucólicas estão entre os registros literários mais antigos do cometa/estrela de César. O astrum caesaris não passou despercebido ao poeta de Mântua que na Nona Bucólica faz uma breve alusão ao fenômeno. Foi através das Bucólicas que Virgílio ganhou notoriedade no mundo da poesia latina, ao emular as composições do poeta helenístico Teócrito de Siracusa, denominadas Idílios. Segundo Pablo Ingberg, em sua introdução para a edição bilíngue da Editora Losada, bucólica é a transcrição latina de boukoliká, adjetivo neutro plural substantivado de boukólos, 'pastor de gado', e significa literalmente 'coisas de pastores' ou 'cantos pastoris' (INGBERG, 2004, p. 14).

Tal como na comédia latina, os personagens preservam os nomes gregos, porém, Virgílio transcria ${ }^{14}$ a forma e os temas da poesia pastoril, enriquecendo a literatura latina a fim de adequá-la ao gosto do público romano. Nas Bucólicas sobejam referências à topografia itálica, aos mitos e aos deuses latinos. Esses diálogos não ocorrem em mundo idealizado ou uma imperturbável paisagem idílica pois, vez ou outra, são permeados com alusões às mazelas das Guerras Civis e aos confiscos de propriedades. Charles Martindale, no capítulo 'Green politics: the Ecogles' presente no Companion to Virgil, sugere que é um lugar comum entre os estudiosos admitir que Virgílio politiza o espaço pastoril, permitindo que elementos de uma realidade mais ampla nele adentrassem (MARTINDALE, 1997, p. 109). Assim, já na Antiguidade, os escoliastas depuraram das Bucólicas supostos indícios biográficos de Virgílio e buscaram no cenário de pastores poetas, alusões pontuais ou alegóricas ao período de sua composição. De acordo com a Vita Vergilit5, o formoso Alexis por quem o pastor Córidon arde de amores na Segunda Bucólica não é outro senão Alexandre, um escravo por quem Virgílio se enamorou e quis imortalizar no poema (SUETÔNIO, Vida de Virgílio, 09; VIRGÍLIO, Bucólicas, II, 1-5). Não é de se estranhar que o tão comentado confisco de propriedades na região da Gália Cisalpina, que afetou diretamente a vida do poeta, seja uma chave de leitura para as imprecações de Méris contra o estranho que se apossou de suas terras (VIRGÍLIO, Bucólica, IX. 02-06).

Não apenas os importunos mais sensíveis da política dos Triúnviros, mas os acontecimentos associados à consecratio de César, direta ou indiretamente, reverberaram na poesia pastoril. Divididas em breves poemas, compostos em hexâmetro 
dáctilo (média de noventa versos em cada poema), as Bucólicas apresentam pastores em conversações e disputas poéticas sobre temas amorosos, mitológicos e a faina dos rebanhos. Lícidas, um dos pastores poetas das Bucólicas, recorda uma curta composição de seu colega, Méris

[Daphni, quid antiquos signorum suspicis ortus? Ecce Dionaei processit Caesaris astrum, astrum quo segetes gauderent frugibus et quo duceret apricis in collibus uua colorem] (VIRGÍLIO, Bucólica, IX, 46-49).

[Dáfnis, por que olhas o nascer antigo das constelações? já que avança o astro de César, descendente de Dione astro com o qual as searas se alegrarão com espigas e as uvas ganharão cor nas encostas soalheiras](Trad. de Maria Isabel Rebelo Gonçalves).

Considerado um dos mais antigos registros textuais do corpo celeste, o trecho acima vislumbra este novo astrum casesaris exercendo benéfica influência sobre a terra. Deve o agricultor esperar abundância e um novo tempo prometido pela passagem do astro. Com Dionaei processit, Virgílio remete à genealogia familiar dos lulii e à vinculação mais direta de César com Vênus. Dione é uma das deusas da primeira geração, filha de Urano e Tétis, por vezes citada como mãe de Afrodite e com ela confundida (GRIMAL, 2014, p. 128). Cumpre assinalar que Virgílio opta pela palavra astrum no lugar de cometes ou sidus crinitus para descrever o corpo celeste.

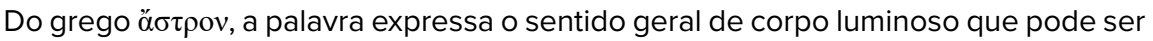
tomado como sinônimo de estrela e, no plural, alusivo às moradas celestes (GLARE, 1968, p. 193). No trecho acima, o astro de César se destaca em relação aos antigos signa $^{16}$ que podem ser traduzidos, mais diretamente, por constelações (GLARE, 1968, p. 1760). Tanto signa quanto astra são termos intercambiáveis na poesia virgiliana, como por exemplo, em relação às constelações do Zodíaco (VIRGÍLIO, Geórgicas, I, 232, 236 e 239). Logo, a referência deve ser compreendida a partir da utilização dos astros como marcadores anuais do ciclo agrícola e o astrum caesaris anunciado como um propiciador de abundância.

Segundo Nandini B. Pandey, no artigo "Caesar's Comet, the Julian Star, and the Invention of Augustus", esta passagem, muitas vezes, tomada como um exemplo de "propaganda augustana" pelos manuais escolares deve ser problematizada no contexto das próprias Bucólicas (PANDEY, 2013, p. 424). Assim, o otimismo subjacente ao portento da estrela de César contrasta nitidamente com as queixas de Méris, no início da Nona Bucólica, a respeito das mazelas e confiscos trazidos pela guerra. Alguns versos mais a frente, o próprio autor da composição, Méris, admite tê-la esquecido - nunc oblita mihi tot carmina - e que agora sua voz falhava - uox (...) fugit (VIRGILIO, Bucólicas, IX, 53-54). 


\section{Os Portentos da Morte de César e os Diri Cometae no Livro I das Geórgicas}

Apesar de não existir qualquer referência direta ao astrum caesaris nas Geórgicas, os fenômenos celestes formam parte de seu repertório temático. Em dois mil cento e oitenta e oito hexâmetros, divididos em quatro livros, as Geórgicas exaltam a vitalidade do solo Itálico, em uma espécie de poesia didática que mescla elementos técnicos com excursus mitológicos e históricos (TREVIZAM, 2014). De acordo com a Vita Vergili, as Geórgicas foram compostas ao longo de sete anos, a partir de uma suposta incumbência recebida de Mecenas. Em 29 a.C., Virgílio teve a oportunidade de recitar o poema na íntegra para a comitiva do Princeps que regressava das campanhas do Oriente. Esta performance teria durado quatro dias, até o esgotamento vocal do poeta (SUETÔNIO, Vida de Virgílio, 27). O título da obra deriva do adjetivo grego үعwpүıкóc que qualifica alguém versado ou habilidoso nos assuntos agrícolas e, ao mesmo

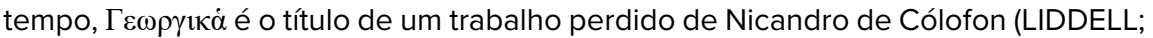
SCOTT, 1996, p. 347). Os quatros primeiros versos do proêmio são necessariamente um resumo de toda a obra

[Quid faciat laetas segetes, quo sidere terram uertere, Maecenas, ulmisque adiungere uitis conueniat, quae cura boum, qui cultus habendo sit pecori, apibus quanta experientia parcis, hinc canere incipiam] (VIRGÍLIO, Geórgicas, I, 1-4).

[O que faz as searas abundantes, qual a melhor estrela na lavoura, quando olmeiros convém ligar às vides, o cuidado com o gado, a experiência tamanha que as abelhas laborantes requerem: a partir de agora vou, Mecenas, cantar.] (Trad. de Arthur Rodrigues Pereira Santos).

No primeiro verso, a palavra seges tem o sentido de safra ou a colheita, enquanto sidus remete à função dos astros e constelações como marcadores das estações e do ciclo agrícola (GLARE, 1968, p. 1727, 1757). O primeiro hexâmetro antecipa a temática do Livro I, dedicado aos trabalhos da agricultura e à arte da observação atenta dos astros e elementos naturais. Este livro termina com o excursus que descreve os vários portentos que anunciam o Cesaricídio e a guerra subsequente contra Cássio e Brutus. As vides e os olmos, em referência no segundo verso, resumem a temática do Livro II, voltado para a viticultura e arboricultura. O Livro III, que se inicia com a promessa do poeta de erigir um Templo a César Otávio, é dedicado à tipologia e à gestão dos rebanhos. A temática é anunciada pela referência aos bois e ao gado miúdo no terceiro verso. Por fim, o quarto hexâmetro resume o mote do Livro IV, direcionado à Apicultura, que traz um dos mais comentados excursus das Geórgicas: o epílion de Aristeu com a descida de Orfeu ao Mundo dos Mortos, em busca de Eurídice.

A dedicação do proêmio é seguida pela invocação das divindades, muitas delas itálicas, como Liber, Ceres, Minerva, Netuno e Silvano, entre as quais César (Otávio) é nomeado. Virgílio projeta a eventual apoteose astral de Otávio ao ressaltar que um espaço entre Erígone (a constelação da Virgem) e as Pinças ${ }^{17}$ se expandia para acolhê-lo no etéreo (VIRGÍlIO, Geórgicas, I, 32-35). Acrescenta ainda que este não 
tem por destino governar o Averno, nem mesmo os Campos Elíseos, ainda que estas moradas fossem apreciadas pelos gregos (VIRGÍLIO, Geórgicas, I, 36-38). Como parte das constelações do Zodíaco, o novo astro, como se refere ao Princeps, seria incorporado às marcações principais do calendário cósmico na faixa da eclíptica (VIRGÍlIO, Geórgicas, I, 32; VOLK, 2014, p. 1409-1410).

Os astros são anunciados como aliados essenciais nos labores do campo, comparados ora ao campo de batalha, ora aos trabalhos do mar (VIRGÍLIO, Geórgicas, I, 160-161; 204-205). O poeta ressalta que não é em vão que o camponês toma nota do nascer - ortus - ou do ocaso - obitus - das estrelas uma vez que delas depende para se orientar em relação às estações do ano (VIRGÍLIO, Geórgicas, I, 257). Pertinente ao tipo de cultivo almejado (trigo, cevada, lentilhas, linho), compete ao agricultor estar atento ao orto helíaco ${ }^{18}$ e aos poentes de algumas estrelas e constelações de referência (Arcturo, Plêiades, Cão) e também ao trajeto do Sol pela faixa do Zodíaco. Em consonância com o proêmio, algumas das narrativas mitológicas de asterização aparecem neste breve inventário astronômico do primeiro livro.

Em uma parte do Livro I das Geórgicas, voltada à observação do ano agrícola através dos astros estacionais, o poeta alude ao mito de Calisto: "claramque Lycaonis Arcton" - a ursa brilhante de Licáon [tradução nossa] - (VIRGÍlIO, Geórgicas, I, 138). Filha de Licáon, rei da Arcádia, Calisto era uma das virgens companheiras de Diana que acabou vítima das artimanhas sedutoras de Zeus. A jovem, que foi metamorfoseada em ursa, acabou mortalmente ferida por uma flecha, recebendo como recompensa a apoteose sideral. O mito de Calisto compreende a etiologia astral para a constelação conhecida como Ursa Maior e aparece em outros poetas da Antiguidade ${ }^{19}$. Juntamente com a Ursa Menor, consiste em uma constelação polar cujo arco de visibilidade é permanente no céu. Em razão disso, o poeta acrescenta mais à frente no texto que as "As ursas tementes de se banhar na planura do Oceano [tradução nossa]" - Arctos Oceani metuentis aequore tingi (VIRGÍLIO, Geórgicas, I, 246).

Ainda no primeiro livro das Geórgicas, Virgílio remete aos catasterismos das Plêiades e de Ariadne, associada à constelação Corona Borealis. Recomenda que o agricultor, antes de dar início à semeadura do trigo, aguarde "Que as matutinas Atlântides se escondam de ti / e que a Estrela Cnóssia de ardente Coroa se retire [tradução nossa]" - ante tibi Eoae Atlantides abscondantur / Cnosiaque ardentis decedat Stella Coronae (VIRGÍLIO, Geórgicas, I, 221-222). Por Stella Cnossia ou "estrela de Cnossos" o poeta se refere à filha de Minos, Ariadne, que, depois de ser abandonada por Teseu, foi resgatada pela comitiva de Baco. Enamorado da jovem, o deus a desposou, levando-a para o Olimpo ${ }^{20}$. Como presente de núpcias, Ariadne recebeu uma coroa, forjada por Hefaísto, que foi transformada em constelação. Já as 'Atlântides' são um dos epítetos das Plêiades, as sete filhas de Atlas que foram divinizadas e convertidas em constelação. O orto helíaco das Plêiades marcava, no calendário Juliano, o começo do verão (maio), enquanto seu ocaso matutino aparente, referenciado no verso acima, ocorria no princípio do inverno ${ }^{21}$ (novembro). Por sua vez, o ocaso helíaco da Coroa de Ariadne acontecia nas primeiras semanas de novembro, indicando ao agricultor o ensejo para a sementeira dos cereais de inverno. 
A entonação otimista do proêmio e dos catasterismos de Calisto, Plêiades e Ariadne formam um contraste com os últimos cinquenta versos do Livro I. Rememorada nas Geórgicas, a morte do Ditador é caracterizada como a quebra da ordem natural, acompanhada de prodígios agourentos. O sol que, segundo o poeta, fornece aos homens avisos sobre os infortúnios e tumultos vindouros, deixou de brilhar nesta ocasião, como ilustram os versos 465-467, do livro I das Geórgicas: "[...] ille etiam exstincto miseratus Caesare Romam, / cum caput obscura nitidum ferrugine texit / impiaque aeternam timuerunt saecula noctem.", isto é, "Por César morto, o sol compassivo cobriu / a cabeça luminosa e Roma com ferrugem sombria / e os ímpios séculos terão temido a noite eterna" [tradução nossa].

Ao contratempo solar, Virgílio acrescenta um conjunto de sinais funestos que intensifica o cenário de perturbação cósmica traduzido pela ideia de aeterna nox nos versos acima. Nas Geórgicas, aves agourentas, cadelas sinistras, espectros de intensa palidez, animais falantes e, até mesmo, uma erupção do Etna são arrolados como prodígios perturbadores (VIRGÍLIO, Geórgicas, I, 469-475). Como sinédoque para as estátuas dos deuses Virgílio acrescenta que "nos templos, chora o marfim aflito e suam os bronzes [tradução nossa]" - maestum inlacrimat templis ebur aeraque sudant (VIRGÍlIO, Geórgicas, I, 480). Para assinalar a interrupção da pax deorum, o poeta lança mão ainda do vocabulário da aruspicia uma vez que alude aos "nódulos ameaçadores" - fibrae minaces - surgindo nas vísceras das vítimas (VIRGÍLIO, Geórgicas, I, 484). À lista de prenúncios ameaçadores do Cesaricídio, o poeta acrescenta aqueles que foram relatados na região celeste, como fica evidente no trecho compreendido entre os versos 485 e 488 do livro I das Geórgicas: “(...) altae / per noctem resonare lupis ululantibus urbes. / Non alias caelo ceciderunt plura sereno / fulgura nec diri totiens arsere cometae.", isto é, “(...) Durante / a noite, com lobos uivantes ressoam as cidades. / Nem do céu sereno, em outras caíram clarões / muitos, nem cometas funestos arderam tanto" [tradução nossa].

Como discutiremos adiante, os cometas eram percebidos, em geral, como uma alteração da ordem imutável do céu e, dentro do repertório das premonições, lidos como mensageiros de calamidades, em especial, àquelas referentes à guerra. Aplicado comumente aos presságios (omina), o adjetivo dirus (plural diri), é usado na linguagem poética para designar ações, monstruosidades ou pessoas que inspiram o terror: como as Fúrias na Eneida (VIRGÍLIO, Eneida, II, 261, 276; VII, 324)²2.

No trecho em questão a aparição dos cometas antecede um conjunto de flagelos vindouros como a guerra e o derramamento de sangue, anunciados nos hexâmetros seguintes:

[ergo inter sese paribus concurrere telis

Romanas acies iterum uidere Philippi;

nec fuit indignum superis, bis sanguine nostro

Emathiam et laetos Haemi pinguescere campos]

(VIRGÍlIO, Geórgicas, I, 489-492). 
[Viram por isso os campos de Filipos, Pela segunda vez, se combaterem Exércitos romanos, pares armas, Sem parecer aos deuses ser indigno Que sangue nosso fosse enriquecer De novo Emátia e vastas terras de Hemo] (Trad. de Agostinho da Silva).

Nestes versos, o poeta refere-se de forma mais explícita aos infortúnios ocasionados pela guerra entre cesarianos e libertadores. As terras de Hemo correspondem ao que hoje é conhecido pela cordilheira dos Balcãs e, em geral, a todo o território que esta cadeia montanhosa abarca, cenário também da batalha de Farsália entre Pompeu e Júlio César. Como é de conhecimento geral, Filipos é o local onde em 42 a.C. se enfrentaram os exércitos de Marco Antônio e Otávio contra os de Bruto e Cássio, na fronteira entre a Macedônia e a Trácia. O advérbio iterum, "pela segunda vez", provavelmente remete a reincidência da Guerra Civil e o embate decisivo acontecendo em território de língua grega. Ettore Paratore aponta para a proximidade fonética da palavra Emátia e Hemo da palavra grega $\alpha \tilde{i} \mu \alpha$ ou "sangue" o que reforça a natureza cruenta deste conflito, seguimento das inúmeras catástrofes listadas pelo poeta (PARATORE, 1938). Ao fim do Livro I das Geórgicas, Otávio é exaltado como aquele jovem destinado a socorrer um século [ou geração] perturbado, porém o excursus virgiliano termina com uma velada crítica à paixão do jovem César pelos triunfos e com a imagem de uma carruagem desgovernada, comparada à fúria de Marte (VIRGÍLIO, Geórgicas, I, 500-514).

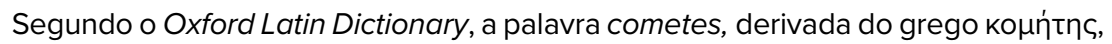
refere-se a um corpo luminoso com uma coma, ou rastro e, em geral, era percebido como um portento de mau augúrio (GLARE, 1968, p. 359). Nas fontes latinas, prévirgilianas, esta associação aparece em duas obras de Cícero. No Livro II do tratado Sobre a Natureza dos Deuses, entre os vários prodígios capazes de aterrorizar a mente, como os raios, chuvas de pedras, pestilências e terremotos, Cícero cita os cometas:

[(...) tum facibus visis caelestibus tum stellis is quas Graeci kouńtac nostri cincinnatas vocant, quae nuper bello Octaviano magnarum fuerunt calamitatum praenuntiae (...)]

(CÍCERO, Sobre a Natureza dos Deuses, II, 14).

[(...) então, pelas luzes celestes vistas - os meteoros - e pelas estrelas, que os gregos chamam de kouńtas [astro comado] e que os nossos chamam de cincinnatas $^{23}$ [de madeixas aneladas] e que recentemente na Guerra Otaviana foram mensageiras de grandes calamidades (...)] (Tradução nossa).

Cícero faz referência ao possível aparecimento de um cometa em 87 a.C., ano que foi marcado pela conjunção de eventos fatídicos, como a Guerra Civil, a morte dos Cônsules Gneu Otávio e Lúcio Cornélio Merula e uma praga devastadora. Ramsey, em seu mais recente estudo "A Descriptive Catalogue of Greco-Roman Comets from 500 B.C. to A.D. 400" sugere que a passagem deste astro, em 87 a.C., pode ter contribuído 
para reforçar na memória romana a ideia de que cometas eram presságios de guerra e pestilência, sendo que esta percepção negativa dos cometas não se desenha como um modelo na literatura grega precedente ${ }^{24}$ (RAMSEY, 2006, p. 96). Mais uma vez, no tratado Sobre a Adivinhação (44 a.C.), Cícero inclui a visão de "cometas trêmulos de brilho claro" - tremulos ardore cometas - em uma trilha de eventos perturbadores como massacres, eclipses, raios e tremores de terra (CÍCERO, Sobre a Advinhação, I, 11-18). Além da referida passagem das Geórgicas, essa ideia reverbera na Eneida no trecho em que o poeta compara a aparição de Eneias, em batalha, a um cometa sangrento (VIRGÍLIO, Eneida, X, 272). Entre os poetas da geração de Virgílio, a percepção dos cometas como arautos da destruição aparece ainda em Tibulo. No segundo livro das Elegias, o poeta compara o surgimento de um cometa aos "sinais funestos da guerra" belli mala signa cometen" (TIBULO, Elegias, II, 71) ${ }^{25}$.

O excursus que encerra o Livro I das Geórgicas não acena com qualquer possibilidade sobre a apoteose ou catasterismo do Ditador. As expectativas sobre a divinização estão voltadas mais para Otávio, uma vez que o poeta promete sua acolhida entre as constelações do Zodíaco, logo na dedicação do poema. Os diri cometae e todos os anúncios funestos elencados intensificam o pessimismo do cenário que se instaura após a morte de César. No âmbito da polissemia poética, as passagens citadas podem ser consideradas um resquício das percepções plurais acerca do cometa/ estrela de César e de suas consequências no cenário político. Aproximadamente os dez últimos anos de vida do poeta foram dedicados à composição da Eneida que correspondem à primeira década do regime conhecido como Principado.

\section{A Divinização dos Heróis e as Etiologias Astrais na Eneida}

Epopeia redigida em língua latina (29-19 a.C.), a Eneida celebra os feitos do herói troiano Enéias que, guiado pelo destino, lidera um grupo de refugiados até o oeste da Ausônia (Península Itálica), local designado para assentar a nova Tróia. Enquanto os seis primeiros Livros da epopeia são dedicados à jornada marítima de Enéias, os seis últimos retratam as contendas no Lácio. A partir do diálogo com o modelo homérico, Virgílio se reapropria de vários motivos convencionais do épico, de forma a imprimir originalidade ao texto e torná-los palatáveis e compreensíveis ao público/audiência de seu tempo. A ação da epopeia tem como eixo a idade heroica, o período pré-fundacional da urbs, no entanto, através das prolepses, a Eneida abarca acontecimentos que se projetam em um futuro distante. A História de Roma e o próprio tempo do poeta são retroprojetados no futuro de Enéias que é apenas parcialmente visível e cognoscível ao herói, mas que faz todo sentido para os leitores/ ouvintes do poema. Assim, através deste efeito de diluição temporal, o poeta coloca em um mesmo plano narrativo a apoteose dos heróis semideuses, os catasterismos e as aparições do cometa/estrela de César.

Uma das prolepses mais conhecidas da epopeia virgiliana está situada logo no Livro I: a profecia em que Júpiter desvela para Vênus os acontecimentos vindouros da história do Lácio e de Roma, como a fundação de Alba Longa por Ascânio-lulo, o nascimento de Rômulo, a conquista da Grécia e antecipa o próprio tempo de Augusto 
(VIRGÍLIO, Eneida, I, 223-304). Abrangendo um total de quarenta hexâmetros, a profecia do Pai dos Deuses é uma manifestação do favor divino para com a descendência de Enéias. O colóquio divino tem lugar depois da tempestade que ameaça a frota troiana e do desembarque dos refugiados no litoral da Líbia (VIRGÍLIO, Eneida, I, 157-222). Júpiter tenta abrandar aflições de Vênus que teme pela conservação do filho e a realização das glórias que o fatum lhe reserva. Dessa maneira acena com a promessa da divinização do herói troiano:

[sublimemque feres ad sidera caeli magnanimum Aenean; neque me sententia vertit] (VIRGÍLIO, Eneida, I. 257-260).

[O magnânimo Enéias será por ti aos astros sublimado e deste meu propósito não mudo] (Trad. de José Victorino Barreto Feio).

Como é perceptível nesta passagem, o poeta descreve a divinização de Enéias em termos de uma elevação celestial. Uma vez que o verbo fero se encontra na segunda pessoa do singular entende-se que Vênus é anunciada como agente da apoteose do próprio filho. Como sugerem esses hexâmetros, Enéias destina-se ao etéreo e residência dos deuses olímpicos e não ao mundo inferior ou aos Campos Elíseos. No Livro XII, encontramos a repetição da mesma profecia pelo pai dos deuses, em outro diálogo olímpico que antecede o confronto decisivo entre Enéias e Turno (VIRGÍLIO, Eneida, XII, 794-795). O herói já conta com uma reputação que o imortaliza entre os homens e uma fama que o torna conhecido no firmamento - super aethera notus (VIRGÍLIO, Eneida, I, 379). À tradição de um Enéias, desaparecido no rio Numício (CATÃO, Origens, fr. 7a; SÉRVIO, Comentário a Eneida, IV, 620) e cultuado sob o epíteto Indiges, na cidade de Lavínio (CÁSSIO HEMINA, Anais, fr. 08), a Eneida acrescenta a perspectiva de um herói que vai às estrelas, primeiramente, através da fama para então ser arrebatado ao firmamento.

Virgílio parece operar com duas noções de imortalidade que são intercambiáveis e complementares em sua produção poética. Primeiramente, a ideia de uma imortalidade resultado da boa fama ${ }^{26}$ que é cantada pelos versos do poeta e elevada às estrelas e, em segundo lugar, a perspectiva de imortalidade por meio da ascensão sideral, semelhante ao movimento de um catasterismo. Esta boa fama, veículo da glória, aparece na Eneida como uma adaptação da ideia homérica de kléos andron que é a glória cantada pelo aedo, inspirado pelas Musas, que chega aos céus, "kléos ouranòn eurùn hikánei", se tornando kléos aphthiton "glória imorredoura” (SOUZA, 2012, p. 166). Na epopeia virgiliana, essa ínclita fama que vai ad sidera/ad astra se torna uma pré-condição para a apoteose astral - reservada a poucos heróis e semideuses - e com ela se confunde na linguagem poética.

Entre os heróis, semideuses, a morte de Hércules representa o caso mais conhecido de deificação27. No tempo em que decorre a ação na Eneida, Hércules já integra o panteão olímpico e sua apoteose é recordada no episódio da visita de Enéias à Palanteu, cidade fundada pelo árcade Evandro e ao sítio da futura Roma (VIRGÍLIO, Eneida, VIII, 97-183). Passado, presente e futuro estão amalgamados na narrativa, uma vez que o poeta se utiliza de referentes da toponímia religiosa da urbs para construir 
a trajetória do herói troiano. Enéias desembarca no local posteriormente conhecido como Forum Boarium e surpreende Evandro e os árcades durante os preparativos para o sacrifício anual na Ara Maxima. A benevolência de Hércules, protetor da Humanidade, é recompensada com um tributo anual, festas e sacrifícios realizados junto à Ara Maxima para a qual Virgílio apresenta uma etiologia na Eneida (VIRGíLIO, Eneida, VIII, 185-189). Os sacerdotes, que rememoram os trabalhos do herói, clamam o benefício do nume e a aceitação das dádivas: Salue, uera louis prole, decus addite diuis. "Salve de Jove a verdadeira prole, / esplendor acrescentado aos Deuses." (VIRGÍLIO, Eneida, VIII, 301, Trad. José Victorino Barreto Feio).

Para além das apoteoses heroicas, recordadas na Eneida, Virgílio faz alusão a conhecidas etiologias astrais como o mito de Órion e a Constelação do Cisne. O célebre filho de Netuno, desafiador dos deuses, é recordado em algumas passagens da Eneida, seja na forma de Gigante - como no símile para destacar o ímpeto furioso de Mezêncio - ou na forma de constelação, para anunciar a iminência de tempestades ao longo do curso marítimo de Eneias (VIRGÍLIO, Eneida, I, 535; III, 517; IV, 52; X, 763; OLIVA NETO, 2016, p. 876). No Livro X da Eneida, uma versão italiota ${ }^{28}$ do mito de Cicno (Kúkvoc) é apresentada como etiologia para a constelação denominada 'o Cisne'. Por interferência de Apolo, este herói da Ligúria foi metamorfoseado em cisne e alçado ao firmamento, depois de morto:

[canentem molli pluma duxisse senectam liquentem terras et sidera uoce sequentem] (VIRGílIO, Eneida, X 192-193).

[Ali envelhecera e revestido de alva, mórbida pena abandonara as terras e seguiu cantando os astros]

(Trad. de Carlos Alberto Nunes).

O canto do cisne decorre da perda de Faetonte, seu amado, que foi abatido por Júpiter por roubar os cavalos de Hélio (VIRGÍLIO, Eneida, X, 187-190). No Livro X da Eneida, Cicno é apresentado como ancestral de Cupavo, comandante dos povos lígures e importante aliado de Enéias. Sidera, no acusativo plural, indica a nova condição do herói italiota, metamorfoseado nesta constelação localizada ao norte da linha da eclíptica.

Das poucas vezes em que ocorre no singular, no léxico da Eneida, sidus busca demarcar a manifestação de corpos luminosos específicos, como o sanctus sidus, que guia os troianos até o Monte Ida, o Patrium Sidus, estampado no escudo de Enéias, a "lúgubre estrela de Minerva" em referência à tempestade desencadeada pela deusa contra Ájax e Oileu ou hibernum sidus "estrela hibernal", que assinala a estação hostil aos navegantes (VIRGÍLIO, Eneida, II, 700; VIII, 681; XI, 260; IV, 309). Nas Geórgicas, como já assinalamos, a palavra aparece como sinônimo de constelação. O vocábulo aparece mais comumente no plural (sidera) e com propósitos e sentidos variados no texto, por exemplo: como uma referência genérica aos corpos celestes, incluindo a Lua, ou como metonímia para o período da noite (VIRGÍLIO, Eneida, VIII, 141; IX, 239; XI, 136). Em várias ocasiões o poeta emprega sidera (pl.), assim como astra (pl.) e aethera 
(pl.), para delimitar as regiões extremas do firmamento. Este uso é muito comum na construção das hipérboles, a partir dos verbos tollo ou fero, acompanhados do sintagma preposicionado ad, para anunciar algo que chega às alturas: por exemplo, as ondas fluctus - durante uma tempestade; os terríveis clamores - horrendos clamores - de Laoconte; a bravura dos Troianos; ou o ingente pranto - ingentem gemitum - de luto das troianas (VIRGÍLIO, Eneida, I, 103; II, 222; IX, 637; XI, 37).

Por ser justamente o domínio dos deuses, é para as estrelas que os mortais dirigem suas súplicas ou elevam suas preces (VIRGÍLIO, Eneida, I, 94; III, 599-600). As fronteiras celestes não se definem como absolutas na epopeia, assim como a própria condição mortal. Através do efeito de imbricamento de temporalidades, a possibilidade do catasterismo ou apoteose astral é deslocada para o presente do poeta, transformado em um momento singular da História Romana. Não obstante, as representações da forma astral de César aparecem de forma ambígua no texto em consequência das analogias e arranjos provocados pela linguagem poética.

\section{O Patrium Sidus e o Cometa Sangrento na Eneida: Descrevendo as Armas do Herói}

Das poucas vezes em que é mencionado no épico de Virgílio, César aparece como divinizado e a reboque do filho, Otávio Augusto. O trecho que analisamos a seguir demonstra o esforço do poeta de coadunar a genealogia heróico-divina dos lulii à história de Roma. Na Eneida, a estrela de César aparece no Livro VIII, especificamente na descrição do escudo de Enéias cuja decoração é composta com cenas do porvir. Trata-se de uma das passagens mais citadas do poema épico, claramente inspirada no Canto XVIII da llíada no qual Tétis recorre a Hefaístos para confeccionar as armas de Aquiles (HOMERO, Ilíada, XVIII, 478-608). Enquanto na Ilíada o escudo de Aquiles traz uma miniatura da Terra, com cenas da vida comum circundadas pelo 'Rio Oceano', no Escudo de Enéias temos um quadro central, a vitória triunfal de Ácio, orbitado por cenas periféricas, retratando momentos diversos da história romana. Os quadros descritos são o resultado da seleção de uma totalidade. As cenas do escudo transcorrem em uma sequência de conflitos, pactos e violações da fides, seguidas de respostas violentas do poder romano e a colaboração estrita das divindades nos empreendimentos humanos.

Em descompasso com as cenas orbitais da égide heroica, o poeta emprega mais de cinquenta versos na descrição da Batalha do Ácio e do Tríplice Triunfo de Otávio. O maravilhoso perpassa as cenas do passado recente e se faz notar, especialmente, na descrição da contenda naval (31 a.C.), que os versos do poeta transformam em uma luta cósmica (VIRGÍLIO, Eneida, VIII, 675-710). A descrição da batalha de Ácio pouco lembra a narrativa dos historiadores. Segundo Philip Hardie, no livro Virgil's Aeneid: Cosmos and Imperium, através do jogo de antíteses e do engajamento dos deuses no quadro central do escudo, o poeta eleva a batalha histórica do Ácio à importância de uma Gigantomaquia ou Titanomaquia (HARDIE, 1986, p. 120-157). A batalha se desenrola também no plano divino: Vênus, Minerva e Netuno se embrenham 
na contenda contra as divindades egípcias, (VIRGÍLIO, Eneida, VIII, 698-699). Nesta disputa épica Otávio não está sozinho, mas acompanhado das legiões e seus barcos. Ao seu lado se encontram os Penates e os deuses.

[hinc Augustus agens Italos in proelia Caesar cum patribus populoque, penatibus et magnis dis, stans celsa in puppi, geminas cui tempora flamas laeta uomunt patriumque aperitur uertice sidus] (VIRGÍLIO, Eneida, VIII, 678-681).

[César Augusto os Ítalos guiando Ao combate, com os ancestrais e com o povo, com os Penates e com os grandes deuses: A leda fronte flamas lhe respiram sobre a cabeça, a estrela paterna se revela] (Trad. de José Victorino Barreto Feio).

Com 'Estrela Paterna' - Patrium Sidus -, Virgílio refere-se ao prodígio celeste que ocorreu nos céus de Roma em 44 a. C. A estrela anuncia-se - aperio - numa posição orientadora, marcada no verso pelo indicador ablativo uertice - proveniente de vertex - cume, alto ou a parte mais alta da cabeça (GLARE, 1968, p. 145 e 2042). Através do verbo uomo - literalmente, vomitar - o poeta descreve um par de chamas - geminas flammas - que saltam da fronte de Otávio. A pesquisadora Mary Frances Williams observa que os termos conjugados nesta descrição remetem tanto ao elmo de Rômulo quanto à crista do elmo que Enéias ostenta em batalha, comparado por Virgílio a um cometa sanguinolento (WILLIAMS, 2003, p. 8-10; VIRGÍLIO, Eneida, VI, 779; X, 270). Em razão da ambiguidade do trecho e do jogo de referências, não é possível dizer se o poeta está descrevendo algum apetrecho de guerra ou ornamento honorífico ostentado por Otávio (tal como a coroa rostrada de Agripa) ou, se através do amálgama temporal, o poeta desloca a manifestação do Sidus Iulium para o evento do Ácio. A proximidade descritiva com o símile do cometes sanguineus gera ainda mais incerteza sobre o sentido ou mesmo o formato desta estrela paterna estampada na égide do herói (VIRGÍLIO, Eneida, X, 272).

Das duas vezes em que ocorre nos poemas de Virgílio a palavra cometa parece preconizar um quadro de destruição. Além do excursus do Cesaricídio nas Geórgicas, esta ideia reverbera na Eneida uma vez que o poeta, no Livro X, ao descrever visão do elmo de Eneias no campo de batalha, o compara ao efeito de um "cometa sangrento"

[Ardet apex capiti cristisque a uertice flamma funditur et uastos umbo uomit aureus ignes non secus ac liquida siquando nocte cometae sanguinei lugubre rubent aut Sirius ardor ille sitim morbosque ferens mortalibus aegris nascitur et laevo contristat lumine caelum.] (VIRGÍlIO, Eneida, X, 270- 273). 
[Arde a cimeira de Enéias na bela cabeça, o penacho chamas emite sem pausa; o broquel longe fogo irradia. não de outro modo na noite serena enrubesce um cometa sanguinolento o céu vasto, ou na triste estação em que Sírio abrasador sede ardente conduz para os homens e doenças de luz sombria abafando o conspecto risonho da terra] (Trad. de Carlos Alberto Nunes).

No símile citado constrói-se uma analogia clara entre a crista flamejante do elmo e a crinis que era atribuída aos cometas. Em uma espécie de combustão alimentada pela divindade que há em Enéias e, possivelmente, uma manifestação de sua uirtus, as chamas - ignes - emanam também da égide heroica dando a Eneias o mesmo aspecto terrificante dos cometas, tornando-o temível para os adversários no campo de batalha. Esta conjunção de termos entre os substantivos flamma, uertex e o verbo uomo ocorre também na caracterização de Otávio na batalha do Ácio, tema central da écfrase do escudo (VIRGÍLIO, Eneida, VIII, 678-681). Já o aparecimento da estrela Sírio, que compõe o segundo termo deste símile, coincidia com a estação estival que poderia ocasionar a esterilidade dos campos e o aumento das enfermidades ${ }^{29}$. Nandini B. Pandey atenta para a relação de intertextualidade com Homero, considerando que, na llíada, as visões de Heitor e Aquiles, em suas panóplias de guerra, são comparadas ao despontar de astros funestos (PANDEY, 2003, p. 425; HOMERO, Ilíada, XI, 61-67; XXII, 25-29). Essa relação faz sentido, uma vez que esse trecho marca a estreia de Eneias nos conflitos do Lácio e os últimos três livros da Eneida emulam mais diretamente a narrativa das batalhas da llíada. O símile do cometa sangrento precede, em poucos versos, a ocasião da morte de Palante, protegido do troiano, seguida da fúria do herói que provoca um grande morticínio no campo de batalha (VIRGÍLIO, Eneida, VIII, 362509, 510-605). A fúria, que consome o herói o induz a decisões dúbias do ponto de vista moral e, por vezes, ao tratamento inclemente com vários inimigos prostrados ${ }^{30}$.

Alguns elementos da cena central do escudo, forjado pelo deus Vulcano, evocam os acontecimentos do Livro II da epopeia e os prodígios que motivaram o troiano Eneias a abandonar Troia rumo a sua jornada pelo Mediterrâneo. Alguns estudiosos da Eneida atentam para a conexão entre as chamas que emanam da cabeça de Otávio e aquelas que brotam dos cabelos de Ascânio no Livro II (VIRGÍLIO, Eneida, II, 687-93; WAGENVOORT, 1956; WILLIAMS, 2003; PANDEY, 2018, p.36). O prodígio das flamas é confirmado por Júpiter na forma de um trovão e da aparição de uma estrela

[(...) et de caelo lapsa per umbras stella facem ducens multa cum luce cucurrit] (VIRGÍlIO, Eneida, II, 693-694).

[do céu caindo uma estrela, que após trazia um facho com muita luz, correu por entre as trevas] (Trad. de José Victorino Barreto Feio). 
O evento é celebrado pelo ancião, Anquises, como sanctus sidus (VIRGÍLIO, Eneida, II, 700). Sérvio sugere que o curso desta estrela fugaz é interpretado como um portento favorável - prosperum - justamente por vir da esquerda, tendo em vista a ciência augural na qual Anquíses era instruído (SÉRVIO, Comentário à Eneida, II, 693). Apesar de as palavras sidus e stella serem os referentes mais usuais para estrela ou constelação, corpos luminosos estáticos, através do verbo curro, o poeta exprime a ideia de movimento e órbita para o objeto. O "facho com intensa luz" e a trajetória apresentada, de cima para baixo, sugerem qualquer semelhança com um meteoro em queda. O curso do portento astral indica aos troianos que deveriam se reunir no Monte Ida para, assim, darem início à peregrinação pelo mar até o litoral itálico. A armada de Enéias é construída em um povoado denominado Antandro com a madeira sagrada deste monte que hospeda os cultos de Cibele (VIRGÍLIO, Eneida, III, 06-08). Tanto a flama de lúlo quanto o sidus remetem a predestinação da Gens Iulia no âmbito do favorecimento do fatum.

\section{Considerações Finais}

Virgílio na arquitetura da Eneida comprime diversas temporalidades ao mesmo tempo em que dilui as fronteiras entre o passado heroico, pré-fundacional ao passado recente, na forma de uma memória compartilhada com seus interlocutores. Como buscamos destacar, a apoteose astral e os exemplos de catasterismo na literatura precedente e no vocabulário de Virgílio são referências importantes para nos acercarmos das apropriações poéticas da morte e divinização de César. A ausência de precedentes históricos recentes para o caso estimulou, entre os autores da geração de Virgílio, toda sorte de comparação com a idade heroica que resultou em algumas narrativas sui generis da apoteose dos semideuses, como é o exemplo da versão virgiliana para a divinização de Enéias. Como divindade integrada ao Olimpo, Hércules lança expectativas sobre a divinização de Enéias e sua prole distante nas figuras de César e, até mesmo, de Otávio. Esta apoteose é representada não apenas pelo culto dedicado aos heróis deificados, mas principalmente pelo vocabulário sideral empregado na epopeia.

Pensamos por bem analisar a recorrência do evento astral nos poemas de Virgílio que ganhou diferentes apropriações em cada fase de sua produção poética. As esperanças depositadas no novo saeculum, anunciado pela passagem do astrum caesaris da Nona Bucólica, foram frustradas pela irrupção das animosidades entre os Triúnviros Antônio e Otávio, inquietações que transparecem nos versos das Geórgicas e, até mesmo, na Eneida. Se existiu qualquer forma de manipulação deste portento celeste ou da imagética do cometa associado ao Diuus lulius trata-se provavelmente um aspecto tardio do governo de Augusto e não corresponde às fontes literárias do Segundo Triunvirato e início do Principado.

Não existe imagem coerente ou linear no tratamento que Virgílio confere à estrela/ cometa em sua produção poética. As duas ocorrências da palavra cometes(ae) no léxico virgiliano estão associadas, inicialmente, aos portentos nefastos do Cesaricídio nas Geórgicas e ao contexto da guerra na Eneida. Virgílio opta por designar o fenômeno 
astral de 44 a.C., mais diretamente pelas palavras astrum e sidus em diálogo com o repertório literário dos catasterismos que é familiar aos poetas latinos. Por outro lado, a analogia poética entre o Patrium Sidus, estampado no escudo de Enéias, e o cometes sanguineus não deixa de gerar ambiguidade, cabendo considerar as múltiplas possibilidades na decodificação hermenêutica deste objeto. Como destacamos em nossa análise, os cometas podiam representar uma perturbação na regularidade celeste, representada pelo ciclo regular dos ortos e poentes das estrelas e constelações.

Na versão oficial, o Sidus lulium emplacou: o astro contemplado nos céus de Roma em 44 a.C. foi reconhecido como a anima de César, uma vez que os Triúnviros e mais especificamente o herdeiro, Otávio, representaram o lado vitorioso da competição política. Não podemos esquecer, no entanto, que os Idos de Março foram comemorados nas moedas de Marco Bruto, assim como a Libertas e a figura do Ancestral Lucio Brutus, Cônsul fundador da República (RRC 508/3). Os denominados libertadores queriam ultrajar o cadáver de César, arrastando-o com um gancho pelas ruas de Roma para então atirá-lo no Tibre. O Ditador não apenas foi poupado de tão lastimável destino, mas, através de um longo e controverso processo, transformado em Diuus lulius.

\section{Referências}

BELTRÃO, Cláudia Rosa. Diuus lulius: Cícero e a divinização de Júlio César (Philippica 2). Calíope: Presença Clássica, Rio de Janeiro, n. 26, p. 31-46, 2013.

BOYD, Barbara Weiden. Wordplay and the Catasterism of Chiron in Ovid Fasti 5. The American Journal of Philology, Johns Hopkins, Vol. 122, No. 1, p. 67-80, 2001.

CRAWFORD, Michael. Roman Republican Coinage. Cambridge: University Press, 1971.

DOMENICUCCI, Patrizio. Catasterismo, Astrologia e Astronomia nell'Impero. In: ABBONDANZA, Letizia.; COARELLI, Filippo (orgs.). Apoteosi da Uomini a Dei. II Mausoleo di Adriano. Roma, Museo Nazionale di Castel Sant’Angelo. Roma: Munus, 2014.

EVANS, James. The History and Practice of Ancient Astronomy. Oxford: Universty Press, 1998.

FARREL, Joseph; PUTNAM, Michael Courtney Jenkins (eds.). A Companion to Aeneid and it's Tradition. Oxford: Blackwell, 2010.

FONSECA, Rui Carlos. A Memória dos Heróis Gravada nas Estrelas: Eratóstenes e a Épica Portuguesa. In: PÁMIAS, Jordi (ed.). Erathostenes' Catasterisms: Receptions and Translations. Oberhaid: Utopica, 2016. p. 95-110.

FRANCISCO BAUZÁ, Hugo. Virgilio y su Tiempo. Madrid: Akal, 2008.

GALINSKY, Karl. The Anger of Aeneas. The American Journal of Philology, Baltimore, Johns Hopkins University, Vol. 109, No. 3, p. 321-348, 2018. 
GENETTE, Gérard. Palimpsests: la littérature au second degré. Paris: Seuil, 1982.

GLARE, Peter Geoffrey William (ed.). Oxford Latin Dictionary. Oxford: University Press, 1968.

GRADEL, Ittai. Emperor Worship and Roman Religion. Oxford: Claredon, 2002.

GRIMAL, Pierre. Dicionário de Mitologia Grega e Romana. Trad. Victor Jabouille. Rio de Janeiro, Bertrand Brasil, 2014.

GURVAL, Robert. Caesar's Comet: The Politics and Poetics of an Augustan Myth. Memoirs of the American Academy in Rome, University of Michigan, v. 42, p. 39-71, 1997.

GURZADYAN, Vahagn; VARDANYAN, R. Halley's Comet on the Coins of Armenian King Tigranes? Astronomy \& Geophysics, Oxford University, Volume 45, Issue 4, p. 4-6, 2004.

HAMP, Eric. P. Latin Sidus, Sidera. The American Journal of Philology, Baltimore, Johns Hopkins University, v. 96, n. 1, p. 64-66, 1975.

HARDIE, Philip. Virgil's Aeneid: Cosmos and Imperium. Oxford: University Press, 1986.

INGBERG, Pablo. Introducción. In: VIRGILIO. Bucólicas. Trad. Pablo Ingberg. Buenos Aires: Losada, 2004.

Instituto de Tecnologia da Califórnia. Órbita do C/-43 K1. Disponível em: <https://ssd. jpl.nasa.gov/sbdb.cgi?sstr=-43K1>. Acesso em: 17 Mai. 2020.

KENNEDY, Duncan F. 'Augustan' and 'Anti Augustan': Reflections on Terms of Reference,” In: POWELL, Anton (ed.). Roman Poetry and Propaganda in the Age of Augustus. Bristol, 1992.

KOORTBOJIAN, Michael. The Divinization of Caesar and Augustus: Precedents, Consequences, Implications. Cambridge: University Press, 2013.

LIDDEL, Henry George; SCOTT, Robert (eds.). A Greek-English lexicon. Oxford: Clarendon Press, 1996.

LIPKA, Michael. Roman Gods: A Conceptual Approach. Leiden: Brill, 2009.

MALHADAS, Daisi; DEZOTTI, Maria Celeste Consolin; NEVES, Maria Helena de Moura (eds.). Dicionário Grego Português. Cotia: Ateliê Editorial, 2008.

MARDSEN Brian G. Preface. In: RAMSEY, John T..; LICHT, A. Lewis. The Comet of 44 B.C. and Caesar's Funeral Games. Atlanta: Scholars Press, 1997. p. xv-xvii.

MARTINDALE, Charles. Green politics: the Ecogles. In: MARTINDALE, Charles (org.). The Cambridge Companion to Virgil. Cambridge: University Press, 1997. p. 107-124.

MOTA, Thiago Eustáquio Araújo. O Motivo Épico da Imortalidade Heroica e os Desdobramentos Semânticos da Fama a Partir da Eneida de Virgílio. PHOÎNIX, Rio de Janeiro, v. 24, n. 2, p. 90-107, 2018. 
NETO, João Ângelo Oliva. Apresentação e Notas à Edição da Eneida. In: VIRGÍLIO. Eneida. Trad. Carlos Alberto Nunes. São Paulo: Editora 34, 2016.

PANDEY, Nandini B. 'Caesar's Comet, The Julian Star and the Invention of Augustus'. Transactions of the American Philological Association. Maryland, n. 143, p. 405-449, 2013.

PANDEY, Nandini B. The Poetics of Power in Augustan Rome: Latin Poetic Response to Early Iconography. Cambridge: University Press, 2018.

PARATORE, Ettore. Introduzione alle Georgiche. Palermo: F. Ciuni, 1938.

Portal Science da NASA. Disponível em: <https://solarsystem.nasa.gov/asteroidscomets-and-meteors/comets/oumuamua/in-depth/>. Acesso em: 17 Mai. 2020.

PUTNAM, Michael Courtney Jenkins. The Poetry of the Aeneid: Four Studies in Imaginative Unity and Design. Harvand: University Press, 1965.

PUTNAM, Michael Courtney Jenkins. The Humanness of Heroes: Studies in the Conclusion of Virgil's Aeneid. Amsterdam: University Press, 2011. (The Amsterdam Vergil lectures, 1)

RAMAGE, Edwin S. Augustus' Treatment of Julius Caesar. Historia 34, p. 223-45, 1985.

RAMSEY, John T. A Descriptive Catalogue of Greco-Roman Comets from 500 B.C. to A.D. 400 (= Syllecta Classica 17.) lowa City: University of lowa Press, 2006.

RAMSEY, John T. Mithridates, the Banner of Ch'ih-Yu, and the Comet Coin. Harvard Studies in Classical Philology, Harvard University, Vol. 99, p. 197-253, 1999.

RAMSEY, John T.; LICHT, A. Lewis. The Comet of 44 B.C. and Caesar's Funeral Games. Atlanta: Scholars Press, 1997.

RÜSEN, Jörn. Reconstrução do Passado. Brasília: Ed. Unb, 2010.

SCHILLING, Robert. Apoteosi. In: Enciclopedia Virgiliana. Roma: Istituto della Enciclopedia Italiana, 1984. p. 228-229.

SMITH, Christopher; POWELL, Anton (eds.). The Lost Memoirs of Augustus and the Development of Roman Autobiography. Swansea: Classical Press of Wales, 2009.

SMITH, William (ed.). A Dictionary of Greek and Roman Biography and Mythology. London: J. Murray, 1890.

SOUZA, Marcelo Miguel de. Os aspectos poético-musicais nas obras de Homero: métrica, ritmo e performance (Séc. VIII a. C.). 2012, 184 f. Dissertação (Mestrado em História) - FH, UFG, Goiânia.

SUMI, Geoffrey S. Ceremony and Power. Performing Politics in Rome Between Republic and Empire. Michigan: University Press, 2008. 
SUTHERLAND, Carol Humphrey Vivian. The Roman Imperial Coinage. v. 1. London: Spink and Son Limited, 1984.

SYME, Ronald. The Roman Revolution. Oxford: Clarendon Press, 1939.

TAYLOR, Lily Ross. The Divinity of the Roman Emperor. Philadelphia: Porcupine, 1975.

TRACY, Jonathan. Catasterism. In: THOMAS, Richard F.; ZIOLKOWSKI Jan M. (eds.). The Virgil Encyclopedia. New Jersey: John Wiley \& Sons, 2014. p.244.

TREVIZAM, Matheus. Poesia Didática Antiga: Virgílio, Ovídio e Lucrécio. Campinas: Ed. Unicamp, 2014.

VOLK, Katharina. Zodiac. In: THOMAS, Richard F.; ZIOLKOWSKI Jan M. (eds.). The Virgil Encyclopedia. New Jersey, John Wiley \& Sons, 2014. p. 1409-1410.

WAGENVOORT, Hendrik. Virgil's Fourth Eclogue and the Sidus lulium. Studies in Roman Literature, Culture and Religion, Leiden, p. 1-29, 1956.

WEBB, Ruth. Ekphrasis, Imagination and Persuasion in Ancient Rhetorical Theory and Practice. London: Ashgate, 2009.

WEINSTOCK, Stefan. Divus Iulius. Oxford: Clarendon Press, 1971

WILLIAMS, Mary Frances. The Sidus lulium, the divinity of men, and the Golden Age in Virgil's Aeneid. Leeds International Classical Studies, Leeds, v. 2. n.1, p. 01-29, 2003.

ZANKER, Paul. The Power of Images in the Age of Augustus. Transl. A. Shapiro. Ann Arbor: University of Michigan Press, 1988.

\section{Fontes}

ARISTOTLE. Metereologica. Transl. H.D.P. Lee. Harvard: University Press, 1967. (The Loeb Classical Library)

CALLIMACHUS. The Fragments: The Lock of Berenice. Transl. A. W. Mair. London: William Heinemann, 1931. (The Loeb Classical Library)

CATÃO. Da Agricultura. Trad. Matheus Trevizam. Campinas: Ed Unicamp, 2016.

CATO. Origines. In: CORNELL, Tim J. et al. (ed.). The fragments of the Roman historians. Oxford University Press, 2013.

CATULO. O Livro de Catulo. Trad. João Angelo Oliva Neto. São Paulo: Edusp, 1996.

CÍCERO. Da República. Trad. Amador Cisneiros. São Paulo: Edipro, 2011.

CICERO. De Natura Deorum. Transl. H. Rackham. Harvard: University Press, 1967. (The Loeb Classical Library)

CICERO. On Divination. Book 1. Transl. D. Wardle. Oxford: University Press, 2006. 
DIO CASSIUS. Dio's Roman History. Transl. Earnest Cary. Harvand: University Press, 1924. (The Loeb Classical Library)

DIODORO SICULO. Biblioteca Storica. Trad. Giuseppe Cordiano e Marta Zorat. Milano: Bur, 2014.

ERATÓSTENES. Catasterismos. Trad. Antonio Guzmán Guerra. Madrid: Alianza Editorial, 1999.

FERNANDES, Marcelo Vieira. Manilio - Astronômicas: tradução, introdução e notas. 2006, 289 f. Dissertação (Mestrado em Letras Clássicas) - FFLCH, USP, São Paulo.

HEMINA. Annals. Transl. J. Briscoe. In: CORNELL, T.J. (ed.) et al. The fragments of the Roman historians. Oxford University Press, 2013.

HESIOD. Theogony. Works and Days. Testimonia. Transl. Glenn W. Most. Harvard: University Press, 2006. (The Loeb Classical Library)

HOMERO. Ilíada. Trad. Trajano Vieira. São Paulo: Ed. 34, 2020.

HOMERO. Odisséia. Trad. Trajano Vieira. São Paulo: Ed. 34, 2020.

HORACE. Odes. Transl. Niall Rudd. Harvard: University Press, 2004. (The Loeb Classical Library)

OVID. Metamorphoses. Trad. Hugo Magnus. Boston: Brookes More \& Cornhill Publishing, 1922.

PLINY. Natural History. Transl. H. Rackham. London: William Heinemann, 1967. (The Loeb Classical Library)

SANTOS, Arthur Rodrigues Pereira. A tradução identificadora aplicada ao Livro I das Geórgicas de Virgillio. 2014 108f. Dissertação (Mestrado em Letras Clássicas) - FL, UFRJ, Rio de Janeiro.

SERVIUS HONORATUS, M. Servii Grammatici qui feruntur in Vergilii carmina commentarii. Ed. Georgius Thilo and Hermannus Hagen. Leipzig: Teubner, 1881.

SUETONIUS. 'Life of Vergil' In: SUETONIUS. Lives of Famous Men. Transl. J. C. Rolfe. London: William Heinemann, 1914. (The Loeb Classical Library)

TIBULO. Elegías. Trad. Arturo Soler Ruiz. Madrid: Gredos, 1993.

VIRGIL. Aeneid. Transl. Rushton Fairclough. London: William Heineman, 1916. (The Loeb Classical Library)

VIRGILIO. Bucólicas. Trad. Maria Isabel Rebelo Gonçalves. Lisboa: Editorial Verbo, 1996.

VIRGILIO. Bucólicas. Trad. Pablo Ingberg. Buenos Aires: Losada, 2004.

VIRGÍLIO. Eneida. Trad. Carlos Alberto Nunes. São Paulo: Editora 34, 2016. 
VIRGÍLIO. Eneida. Trad. José Victorino Barreto Feio e José Maria da Costa e Silva (Livros IX - XII). São Paulo: Martins Fontes, 2004.

VIRGÍLIO. Bucólicas, Geórgicas, Eneida. Trad. Agostinho da Silva. Lisboa: Temas \& Debates - Círculo de Leitores, 2012.

VIRGILIO. Geórgicas. Trad. Alejandro Bekes. Buenos Aires, Losada, 2007.

\section{Notas}

1 Mais informações sobre o Oumuamua podem ser encontradas no portal: < ttps://solarsystem. nasa.gov/asteroids-comets-and-meteors/comets/oumuamua/in-depth/ > Acesso em 17 de maio de 2020.

2 Muito se discute sobre a origem etimológica da palavra sidus. Dentro do espectro indo-europeu, os linguistas apontam proximidade com 'svidùs' (Lituânio), 'swidu' (Letônio) de 'brilhar' e ainda com o sânscrito 'svid' de "suar" (HAMP, 1975, p. 64-65; GLARE, 1968, p. 1876). Também é sugerida uma proximidade etimológica com a palavra grega бí̄npoc 'ferro' que, por associação, passa a indicar o local de fundição e venda do metal, de onde derivam as palavras siderurgia, siderúrgica no português (LIDDELL; SCOTT, 1996, p. 1597). Neste sentido, as faíscas produzidas no trabalho do ferro eram associadas ao formato dos corpos estelares.

3 John T. Ramsey é pesquisador do departamento de Estudos Clássicos da Universidade de Illinois em Chicago e A. Lewis Licht do Departamento de Física da mesma universidade. De acordo com este estudo interdisciplinar, o arco provável de observação do cometa teria ocorrido em um intervalo de cinquenta e quatro dias, atingindo o periélio no final de maio. Enquanto o registro nas fontes chinesas data de meados de maio, o cometa foi reportado pelos romanos apenas em julho de 44 a.C. A partir dos parâmetros orbitais os autores argumentam que o cometa poderia ser visto a olho nu, logo nas primeiras horas da manhã, entre fim de maio e julho (RAMSEY; LICHT, 1997, p. 12). Esta regularidade, em parte, explicaria o motivo de o objeto ser representado como uma estrela, por várias fontes romanas. As informações técnicas pertinentes ao registro do C/-43 K1 podem ser acessadas no portal do Instituto de Tecnologia da Califórnia, bem como o modelo da órbita do objeto: https://ssd.jpl.nasa.gov/sbdb.cgi?sstr=-43K1. Acesso em: 17 de maio de 2020. Brian G. Marsden, um astrofísico de Harvard que revisou os cálculos de Licht e redigiu o prefácio do livro, é cético ao avaliar a precisão do registro de Otávio, duas décadas depois do acontecimento. O pesquisador coloca em dúvida se os romanos estariam, de fato, observando um cometa tendo em vista a omissão da cauda nas descrições e o "desconcertante silêncio sobre o fenômeno à noite, quando ele certamente seria mais espetacular” (MARDSEN, 1997, p. XVII).

${ }^{4}$ Segundo Ramsey e Licht, uma das ações de Otávio de 44 a. C. em sua campanha propagandística foi deslocar a data de celebração dos Jogos em Honra de Venus Genetrix, que usualmente ocorriam em setembro, para julho de forma a coincidir com o mês de nascimento do Ditador (RAMSEY; LICHT, 1997, p. 10-11). Por essa razão, em algumas fontes, esta festividade aparece denominada como Jogos à Vitória de César - Ludi Victoriae Caesaris. O aparecimento do cometa durante a festividade teria fortalecido o argumento do herdeiro em aceitar o portento astral como um sinal da apoteose.

5 Tal postura interpretativa ganhou expressão ao longo do século XX com a obra de Ronald Syme (1939), passando por E. Ramage (1985) e Paul Zanker (1988) e pressupõe que Otávio manipulou a opinião pública de forma a dissolver qualquer similaridade incômoda com a memória do Ditador, seja investindo na imagem de César Divinizado ou no título de Filius Diui (PANDEY, 2013, p. 406). 
${ }^{6}$ Nas últimas décadas este modelo cedeu lugar a percepções multifacetadas que levam em conta as peculiaridades políticas, contradições e sutilezas das várias etapas da carreira de Otávio. No campo dos estudos literários, a ideia de que os poetas do período são meros arautos do regime foi colocada em cheque pela escola de Harvard capitaneada por Michael C. J. Putnam. Os acadêmicos ligados a esta corrente buscaram abordagens mais descentralizadas no sentido de captar a subjetividade dos poetas e decodificar mensagens, vozes dissonantes e críticas veladas. Para uma reflexão crítica sobre estas categorias, sugerimos o texto de Duncan F. Kennedy (1992).

7 Marcos Fúrio Camilo (446 a. C.-365 a. C.) pertence aos Furii da cidade de Túsculo que foram integrados aos quadros de cidadãos romanos. Foi eleito Ditador cinco vezes e acumulou quatro triunfos nas guerras contra os équos, os gauleses, os volscos e os etruscos. Públio Cornélio Cipião Africano (236 a. C.-186 a. C.) conduziu os exércitos de Roma na guerra contra Aníbal, derrotando o general cartaginês em Zama (218 a. C). Caio Mário (157-86 a. C.), tio de Caio Júlio César, foi eleito Cônsul sete vezes consecutivas. O mesmo realizou uma reformulação na organização do exército, admitindo os proletarii e cumulou honras ao ter repelido as invasões dos Cimbros e Teutões, de procedência germânica.

8Um importante diálogo do Livro VI da República de Cícero expressa a concepção de que "para todos aqueles, que tiverem defendido a pátria, a sustentado e engrandecido, há no céu um lugar marcado e certo, onde os bem-aventurados regozijam-se pela eternidade [tradução nossa]" omnibus, qui patriam conservaverint, adiuverint, auxerint, certum esse in caelo definitum locum, ubi beati aevo sempiterno fruantur (CÍCERO, República, VI, 13). Duas conhecidas passagens da poesia virgiliana contemplam este entendimento do princípio etéreo/sideral das animae: um trecho das Geórgicas no qual se atribuem às abelhas, em comparação com o gênero humano, parte dos etéreos sopros de forma que podem ascender às estrelas no fim da vida (VIRGíLIO, Geórgicas, IV, 219-220); na descida de Enéias ao mundo dos mortos, na Eneida, o herói troiano recebe do pai, Anquises, instruções sobre o princípio ígneo que anima a lua, as estrelas e os viventes (VIRGÍLIO. Eneida, VI, 724-751). Na linguagem poética de Virgílio essa concepção de matriz filosófica está diluída nas narrativas de metamorfose astral e promessas de divinização.

Os catasterismos se agrupam em torno de temas mitológicos como as aventuras amorosas de Zeus que resultaram, por exemplo, no arrebatamento astral de Ganimedes - vinculado pela figura do copeiro à constelação de Aquário - e Calisto cujo mito é relacionado à constelação da Ursa Maior (ERATÓSTENES, Catasterismos, 1, 26 e 30). Por sua vez, aos trabalhos de Héracles

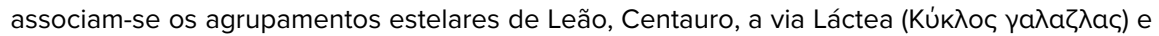
a constelação batizada com o nome do herói, também conhecida como 'O \vyóvađıv, ou "o ajoelhado" (ERATÓSTENES, Catasterismos, 4, 12, 40 e 44). Relacionados à deusa Atena estão os catasterismos de Andrômeda, assim denominada uma das principais constelações do hemisfério norte, e a metamorfose estrelar do herói Perseu (ERATÓSTENES, Catasterismos, 4, 12, 40 e 44 ). Algumas destas etiologias astrais também estão vinculadas a Asclépio, a Apolo e ao ciclo dos Argonautas (ERATÓSTENES, Catasterismos, 6, 19 e 20).

10 Por ocasião da partida do esposo para a guerra contra os selêucidas, Berenice consagrou no Templo de Afrodite Arsione, em Zefirío (sul da Turquia), uma mecha de seus cabelos (CALímACO, Trança de Berenice, fr. 01). O misterioso desaparecimento das madeixas no templo foi atribuído à aceitação da oferenda pelos deuses que se materializou na forma de um sutil agrupamento de estrelas. Não se trata aqui de apoteose, no sentido literal do termo, mas da asterização de um traço mortal da rainha coligado ao orbe celeste. Infelizmente, deste poema sobreviveram alguns poucos fragmentos e boa parte do que conhecemos se devem às citações de Catulo (CATULO, O Livro de Catulo, LXVI, 05-15).

1 Sobre esta temática em Ovídio, sugerimos o artigo de Barbara Weiden Boyd "Wordplay and the Catasterism of Chiron in Ovid Fasti 5". 
12 Através da vivacidade descritiva, o poeta (ou orador) procurava colocar o acontecido ou o ausente na presença do público interlocutor. Segundo Ruth Webb, no livro Ekphrasis, Imagination and Persuasion in Ancient Rhetorical Theory and Practice, o que se esperava da potência verbal do orador ou uates era que esse moldasse e trabalhasse com a galeria mental de seus ouvintes. Lembra essa autora que não podia haver uma dissonância entre o orador, o público e o repertório de signos compartilhados. Nesse sentido, a écfrase é um recurso utilizado para enriquecer a narratio e estimular essa galeria mental compartilhada, possibilitando a visualização do acontecido através de palavras (Cf. WEBB, 2009, p. 131-135).

${ }^{13}$ Esta chave de leitura foi sugerida a partir do diálogo com o helenista Marcelo Miguel de Souza no Grupo de Estudos sobre Épico e Performatividade na Antiguidade (GEEPA).

$14 \mathrm{O}$ entendimento do processo de adoção dos modelos da poesia helênica para a cultura literária latina se dá a partir do processo de que a aemulatio estabelecida não se limitava à mera tradução dos metros e dos lugares-comuns dos modelos escolhidos. Mais do que isso, Virgílio, Horácio e Ovídio, dentre outros poetas, transpõem seus modelos para a literatura latina, transmetrizando-os e tecendo uma rede rica de intertextos, através do jogo alusivo, permitido pela transestilização (Cf. GENETTE, 1982, p. 254-256). Um processo semelhante se deu quando os poetas de nossa língua se apropriaram dos modelos clássicos.

15 Além do relato biográfico que precede o comentário de Sérvio à Eneida, a mais antiga e completa biografia de Virgílio é a que nos chegou pelas mãos do gramático Élio Donato (350 d. C).

${ }^{16}$ A palavra, no plural, é usada por Virgílio nas Geórgicas como sinônimo de constelações, principalmente, em referência àquelas do Zodíaco que assinalam os equinócios de primavera e outono e os solstícios de verão e inverno. No Livro I, Virgílio refere-se à linha da eclíptica, ornada pelas doze constelações (signa) que marca a rota anual do sol e corta obliquamente o equador celeste (VIRGÍlIO. Geórgicas, I, 239). Na História Natural, Plínio o Antigo, distingue mais de setenta tipos de signa ou constelações com formatos de coisas inanimadas ou animais que exercem influência sobre o clima, anunciando tempestades, neve e o início das estações do ano (PLíNIO. História Natural, II, 10. GURVAL, 1997, p. 62).

${ }_{17}$ A Balança era formada, nas representações antigas, pelas Pinças do Escorpião. Segundo Katarine Volk e Jonathan Tracy, Virgílio refere-se aqui a eventual metamorfose de Otávio na constelação de Libra, visto que este signo é uma posterior adição à faixa do Zodíaco (Cf. VOLK, 2014, p.1409-1410; TRACY, 2014, p.244). Sobre a importância do signo de Libra como referência para o horóscopo de Augusto (Cf. MANÍLIO, Astronômicas, IV, 547-552; 773-777).

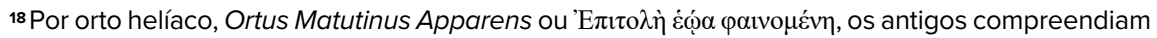
a primeira manifestação visual de uma estrela, depois de um período de oclusão, poucos minutos antes do nascer do sol. A partir de então, a cada dia, o orto desta estrela ocorria quatro minutos mais cedo. O orto helíaco da estrela Sírius marcava, por exemplo, o começo do Ano Sótico no Egito, anunciando o início da cheia do Nilo. Este fenômeno era precedido em alguns dias, ou

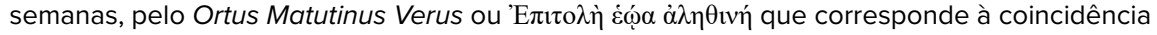
precisa entre o nascimento do sol e a ascensão de determinada estrela. Evento que não podia ser vislumbrado no céu, mas apenas inferido através dos cálculos astronômicos. Entre os fenômenos visíveis das estrelas e constelações os antigos ainda diferenciavam: o orto vespertino, Ortus Vespertinus Apparens, última vez em que se presenciava o nascimento de uma estrela, ainda à luz do crepúsculo; o ocaso matutino, Occasus Matutinus Apparens, primeiro poente visível de uma estrela, pouco antes da aurora e, por último, o ocaso helíaco, Occasus Matutinus Apparens, último poente de uma estrela, no horizonte oeste, à luz do crepúsculo. Para cada um destes fenômenos aparentes havia a correspondência das fases ditas absolutas ou cósmicas (Cf. SMITH, 1890, p. 144-164). Resta dizer que este ciclo de fenômenos está sujeito à localização da estrela/ 
constelação ao norte ou ao sul da eclíptica. Também, em razão da precessão dos equinócios, as datas fornecidas pelas fontes antigas não correspondem aos fenômenos observáveis nos dias atuais para as mesmas constelações. Segundo James Evans, esta diferenciação entre os fenômenos verdadeiros e aparentes das estrelas foi teorizada inicialmente por Autólico de Pitane (Séc IV a. C.) em um trabalho intitulado Sobre os Nascentes e Poentes de Corpos Celestes, mas ela aparece também nos trabalhos de Gêmino de Rodes e Cláudio Ptolomeu (Cf. EVANS, 1998, p. 190).

19 Cf. CATULO, O Livro de Catulo, LXVI. 66. Cf. OVÍDIO, Metamorfoses, I. 165.

20 Sobre a constelação denominada, Coroa Boreal e sua relação com a apoteose de Ariadne confira-se ERATÓSTENES, Catasterismos, 5.

210 ciclo das Plêiades é uma referência não apenas para o calendário agrícola romano. Em Os Trabalhos e os Dias, Hesíodo informa que a estação de aragem deve começar com o ocaso matutino das Plêiades que, ao mesmo tempo, anunciavam o fim das navegações (Cf. HESíODO, Os Trabalhos e os Dias, 381-39). Por sua vez, o poeta recomenda ao agricultor que realize a colheita dos grãos assim que as Plêiades despontem no Oeste (orto helíaco), depois um período de quarenta dias de oclusão (Cf. HESÍODO, Os Trabalhos e os Dias, 381-39).

22 Cf. GLARE (1968, p. 548).

${ }^{23}$ Para o substantivo cincinnus e o adjetivo cincinnatus - $a$ Cf. Glare, 1968, p. 314.

${ }^{24}$ Buscou-se, dentro das escolas filosóficas, explicar estes fenômenos celestes a partir de critérios variados. Aristóteles se ocupou do assunto em alguns capítulos da obra Metereológica. Em síntese, descreve os cometas como acontecimentos naturais, originários dos processos de evaporação da atmosfera terrestre ou de uma estrela (Cf. ARISTÓTELES, Metereológica, 344a-345a). São para o filósofo manifestações infrequentes e temporárias, sem qualquer vinculação direta a portentos nefastos, mas que podem indicar alterações no tempo. Ao propor esta teoria, o filósofo de Estagira busca refutar as explicações de Anaxágoras e Demócrito para os quais os cometas seriam uma conjunção de planetas, quando estes pareciam se tocar devido à proximidade. Refuta também os pitagóricos que tratam os cometas como planetas que se manifestavam com alguma regularidade (Cf. ARISTÓTELES, Metereológica, 342b-343a). Já Zenon de Cicio, fundador do estoicismo, postula que os cometas são uma simples ilusão de ótica, a imagem de uma estrela alongada quando duas ou mais estrelas unem seus raios (Cf. GURVAL, 1997, p. 42). Segundo Gurval, foi provavelmente Panécio de Rodes, da escola estoica, quem influenciou Cícero no tema das diuinationes e propagou esta última teoria. Sobre o uso político desses fenômenos, Mitrídates VI do Ponto, grande antagonista dos romanos, associou seu nascimento e ascensão ao poder com a passagem de um cometa. Várias moedas, cunhadas pelo soberano helenístico, ostentam uma estrela de oito raios com uma cauda. Esta documentação foi analisada por Ramsey (1999) em um artigo intitulado "Mithridates, the Banner of Ch'ih-Yu and the Comet Coin.". Mitridates VI não foi o único governante do período helenístico a utilizar a imagem de um cometa para fins propagandísticos, pois Tigranes II da Armênia, em algumas moedas aparece ostentando uma tiara com um cometa entre duas águias. Sobre estas emissões conferir o estudo de Gurzadyan, V. G. e R. Vardanyan (2004) "Halley's Comet on the Coins of Armenian King Tigranes?".

${ }^{25}$ Entre os autores do período romano essa visão negativa dos cometas não é hegemônica. Para exemplos de cometas recebidos como presságios positivos, sugerimos o já referido estudo de J. Ramsey "A Descriptive Catalogue of Greco-Roman Comets from 500 B.C. to A.D. 400" e o artigo de Robert Gurval "The Politics and Poetics of na Angustan Myth". Basta lembrarmos, também, que a imagem de um cometa acompanhado da legenda SIDVS IVLIVS passa a figurar nas moedas provinciais romanas da década de 10 a. C. e nas emissões do moedeiro M. Sanquinius, em comemoração aos Jogos Seculares (RIC Augustus 37 A e B; 38 A e B e 339 e 340). 
26 Já tivemos a oportunidade de tratar deste assunto no artigo MOTA, Thiago Eustáquio Araújo. O Motivo Épico da Imortalidade Heroica e os Desdobramentos Semânticos da Fama a Partir da Eneida de Virgílio. PHOîNIX, Rio de Janeiro, v. 24, n. 2, p. 90-107, 2018.

${ }_{27}$ Cf. DIODORO SÍCULO, Biblioteca Histórica, IV, 38; Cf. OVÍDIO, Metamorfoses, IX, 98-272.

${ }^{28}$ Em seu Dicionário de Mitologia Grega e Romana, Pierre Grimal enumera, no mínimo, cinco variantes para o mito associadas a diferentes localidades do Mediterrâneo: em algumas narrativas, este aparece como filho de Poseidon, ligado ao ciclo de Troia; em outras, como soberano da região de Tênedos; ora como filho de Ares, salteador dos peregrinos de Delfos e oponente de Héracles; na versão registrada por Virgílio e Ovídio, é o nome de um rei da Ligúria, amante de Faetonte e ainda existe um Cicno, filho de Apolo, da região da Etólia (GRIMAL, 2014, p. 86-87).

29 O efeito devastador da estação de Sírio aparece já no Livro III da Eneida quando o esgotamento dos campos e a pestilência obrigaram os troianos a abandonar o assentamento fundado na ilha de Creta (VIRGÍLIIO, EneidasIII, 142).

30 Para uma discussão mais aprofundada a respeito da fúria do herói troiano e da comparação com o modelo homérico, a partir da relação Aquiles/Pátroclo, sugerimos o artigo de Karl Galinsky (2018) 'The Anger of Aeneas' e o estudo mais recente de Michael Putnam (2011) The Humanness of Heroes: Studies in the Conclusion of Virgil's Aeneid.

Thiago Eustáquio Araújo MOTA é Professor Adjunto de História Antiga da Universidade de Pernambuco (UPE), pesquisador do Laboratório de Estudos sobre o Império Romano, seção UFG (LEIR/UFG) e coordenador do Grupo de Estudos sobre Épica e Performatividade na Antiguidade (GEEPA). Especialista em poesia épica e literatura do Principado. Dentre suas publicações destacam-se: "Troféus de Guerra e a Captura das Armas na Eneida: Morte Violenta e Humilhação do Inimigo In: Margarida Maria de Carvalho; Luciane Munhoz de Omena. (Org.). Narrativas e Materialidades Sobre a Morte nas Antiguidades Oriental, Clássica e Tardia. Curitiba: CRV, 2020, v. 1, p. 80-106. e "Do mercado de livros ao acampamento militar: um estudo da difusão da Eneida no Império a partir das exercitationes scribendi (Romanitas. Revista de Estudos Grecolatinos, 2018). 